\title{
多姿勢対応ダイニングチェアの開発*
}

\section{逸見奈末**, 山崎信寿***}

\begin{abstract}
According to the questionnaires of sitting styles in dining chairs, a large number of people were found to sit in various styles such as "agura", "one-legged agura", and "seiza". The most comfortable seat surface shape for each sitting style was measured using an adjustable experimental chair, which is divided laterally into 16 rigid narrow plates. As a result, following seat-front shape was favored: concaved shape for "agura" and "one-legged agura" style, flat surface for "seiza" style, and convex shape with extended seat for "tatehiza" style. From these results, the seat was divided in two parts. A sliding/rotating frontal seat part is adjustable in its length and angle. In "agura" and "tatehiza" style, a favorable backrest shape were classified in 2 types; straight or convex lumbar shape. Also, thorax-dorsal supporting shape was favored by subjects whom lumbar vertebrae spine have contact with the backrest. Therefore, backrest is curved transversally and the bottom part is softened to bend when pushed by the lower back. Armrests were placed so as not to interfere with the leg positions during "agura". A chair prototype was made following these conditions, and was compared with three commercially available chairs. As a result of sensory evaluation, the prototype was rated higher than the other three chairs in all sitting positions. By putting legs up on the seat, lower leg swelling was reduced, but the contact pressure has increased. By taking various sitting styles, the load of sitting is average out, and longtime sitting can be continued.
\end{abstract}

\begin{abstract}
ダイニングチェアの座り方に関するアンケート調查によって，食後には，あぐらや立て膝，正座などの 姿勢も多くとられていることがわかった．支持面を 16 分割した形状可変実験椅子を用い，それぞれの姿勢 に適した支持面形状を探索した結果，正座では座面を平らにすることを好み，あぐらと片足あぐらでは座 面の前端部を凹型にすることを好み，立て膝では座面を伸ばして座面前端を凸型にすることを好んだ。こ のため, 座面を前後に 2 分割し，前の座面を伸長，傾斜できるようにした。背もたれは，あぐらと立て膝 で腰部をへこませた形状を好む被験者と平面形状を好む被験者がおり，また，棘突起が背もたれに接する 被験者は痛みを避けるために胸背部で支持することを好んだ。このため，背もたれに横 $\mathrm{R}$ をつけ，さらに 下部のクッションを柔らかくし，腰で押されると凹むようにした．肘掛けはあぐら時に大腿が干渉しない 形状寸法とした．試作した椅子を市販椅子 3 脚と比較して官能評価を行った結果，すべての姿勢で高い評 価を得た．また，多姿勢をとることにより，むくみの軽減や圧迫部位を変えるなどの負担部位の交換がで き, 長時間の着座を維持できることがわかった. (キーワード：椅子，姿勢，ダイニングチェア，あぐら，正座
\end{abstract}

\section{1.はじめに}

椅子は，慰部を座面に乗せ，足を下垂させる姿勢を前 提として設計されることが多いが，実際には椅子の上で も図 1 に示すあぐらや立て膝などの様々な姿勢がとられ ている1). 特に, ダイニングなどのリラックスしたプラ イベートな環境では, 人目を気にする必要がないこと と, ダイニングテーブルを使って様々な作業が行われる

* 受付：2006 年 3 月 31 日 受理：2006 年 12 月 14 日

** 慶應義塾大学大学院理工学研究科

Graduate School of Science and Technology, Keio University

*** 慶應義塾大学理工学部機械工学科

Department of Mechanical Engineering, Faculty of Science and Technology, Keio University
ことなどから ${ }^{2)}$, 多様な姿勢がとられている.

学生および社会人（16～56 歳，41名）を対象にした 食卓における姿勢のアンケート結果を図 2 に示す。あぐ らは男性に多く, 立て膝, 横座り, 割り座は女性に多 かった。 また，食事以外では約 $80 \%$ の人が，片足あぐ らなどの座面に足をあげる姿勢をとっていることがわ かった。しかしながら，あぐら ${ }^{3)}$ 以外，このような姿勢 のための快適な椅子条件は必ずしも明らかではない.

本研究では, 多姿勢をとることを前提とした椅子条件 を求め,これらを実現する新たなダイニングチェアを提 案した。 
表 1 被験者特性

Tab. 1 Subjects' characteristics.

\begin{tabular}{|c|c|c|c|c|c|c|c|c|c|c|c|c|c|c|c|c|}
\hline & 性別 & $\begin{array}{l}\text { 身長 } \\
{[\mathrm{cm}]}\end{array}$ & $\begin{array}{l}\text { 体重 } \\
{[\mathrm{kg}]}\end{array}$ & $\begin{array}{c}\mathrm{BMI} \\
{\left[\mathrm{kg} / \mathrm{m}^{2}\right]}\end{array}$ & $\begin{array}{c}\text { 立位体前屈 } \\
\text { [mm] }\end{array}$ & $2-1$ & $2-3$ & $2-4$ & $2-5$ & 3 & 4 & $\begin{array}{l}5-1 \\
\text { 官能 } \\
\end{array}$ & $\begin{array}{l}5-1 \\
\text { 姿勢 }\end{array}$ & $\begin{array}{l}\text { 筋電 } \\
\end{array}$ & $\begin{array}{c}5-2 \\
\text { むくみ }\end{array}$ & $\begin{array}{r}5-2 \\
\text { 体圧 }\end{array}$ \\
\hline 被験者 a & 女 & 145 & 47 & 22.4 & 140 & & & 0 & & & & & 0 & & & \\
\hline 被験者 b & 女 & 152 & 51 & 22.1 & 180 & 0 & 0 & & 0 & 0 & 0 & 0 & & & & \\
\hline 被験者 c & 女 & 154 & 42 & 17.7 & 140 & & & 0 & & & & & 0 & & & \\
\hline 被験者 d & 女 & 156 & 43 & 17.7 & 230 & 0 & 0 & 0 & 0 & 0 & 0 & 0 & 0 & 0 & 0 & 0 \\
\hline 被験者 e & 女 & 160 & 58 & 22.7 & 40 & & & & & & & & & & & \\
\hline 被験者 f & 男 & 162 & 56 & 21.3 & 10 & & & 0 & & & & & 0 & & & \\
\hline 被験者 g & 女 & 163 & 60 & 22.6 & -40 & & & & & & & 0 & & & & \\
\hline 被験者 h & 男 & 164 & 53 & 19.7 & 90 & & & & 0 & & 0 & & & 0 & & \\
\hline 被験者 i & 男 & 164 & 62 & 23.1 & 10 & 0 & & & & & & & & & & \\
\hline 被験者 j & 男 & 165 & 50 & 18.4 & 150 & & 0 & & & & & 0 & & 0 & 0 & \\
\hline 被験者 k & 女 & 165 & 51 & 18.7 & 140 & & & & & & & & & & & 0 \\
\hline 被験者 1 & 男 & 165 & 53 & 19.5 & 60 & & & 0 & & & & & 0 & & & \\
\hline 被験者 m & 男 & 167 & 46 & 16.5 & 10 & & & & & & & 0 & & & & \\
\hline 被験者 n & 男 & 167 & 59 & 21.2 & 150 & & & & & 0 & & & & & & \\
\hline 被験者 o & 男 & 169 & 51 & 17.9 & 80 & & & & & & & & & & & \\
\hline 被験者 $\mathrm{p}$ & 男 & 169 & 52 & 18.2 & -50 & & & & & & & & & & & 0 \\
\hline 被験者 q & 男 & 169 & 53 & 18.6 & 10 & & & & 0 & 0 & & 0 & & 0 & 0 & \\
\hline 被験者 r & 男 & 169 & 55 & 19.3 & 80 & & & & & 0 & & & & & & \\
\hline 被験者 s & 男 & 169 & 72 & 25.2 & 80 & & & & & & 0 & 0 & & & & \\
\hline 被験者 t & 男 & 170 & 72 & 24.9 & 10 & 0 & & & & & 0 & & & & & 0 \\
\hline 被験者 u & 男 & 170 & 84 & 29.1 & 140 & & & & & & & 0 & & & & \\
\hline 被験者 V & 男 & 172 & 62 & 21.0 & 10 & 0 & 0 & & 0 & 0 & & 0 & & & & 0 \\
\hline 被験者 w & 男 & 176 & 61 & 19.7 & -120 & 0 & & & & & & & & & & \\
\hline 被験者 X & 男 & 179 & 66 & 20.6 & 110 & & & & 0 & 0 & & 0 & & & & \\
\hline
\end{tabular}
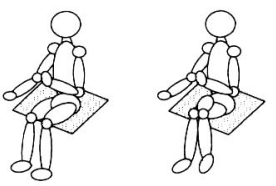

通常座位

足組み

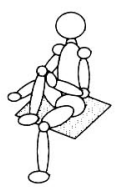

後ろ向き

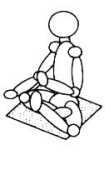

あぐら

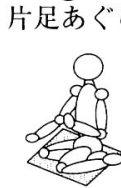

割り座

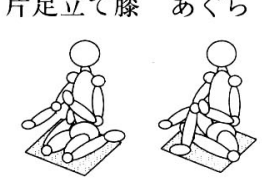

横座り片膝立て

図 1 様々な座り方

Fig. 1 Various sitting styles.

\section{2. 座 面}

\section{2-1．姿勢別の支持面条件の探索}

支持面を 16 分割した形状可変式実験椅子4)を用い,

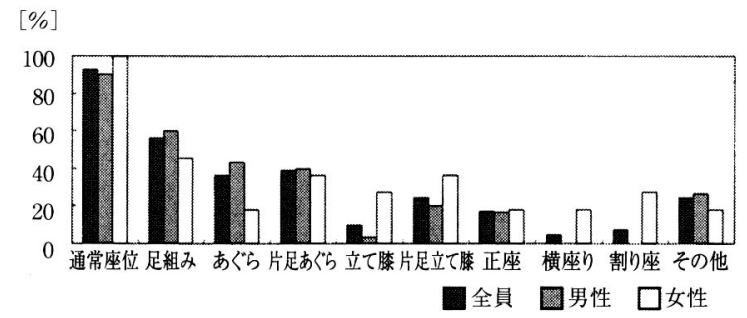

(a) ダイニングチェアでとる姿勢（複数回答）

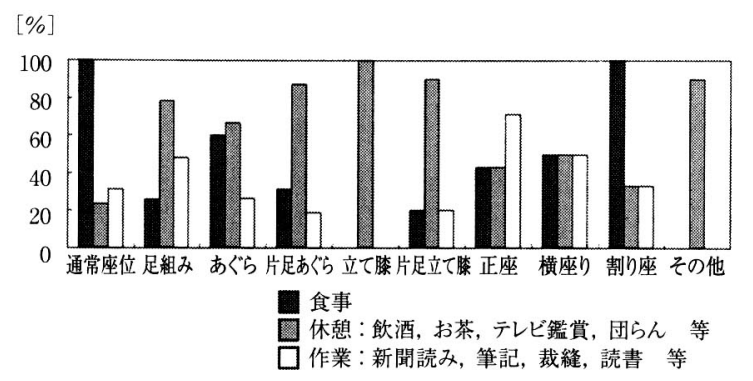

（b）各姿勢における行為（複数回答）

図 2 ダイニングチェアでとる姿勢と行為

Fig. 2 Sitting posture and action taken on dining chairs.

表 1の 2-1 欄（節項番号で表示．以下略）に示す被験者 6 名について, 図 1 の姿勢のなかで頻度が高い通常座 位，片足あぐら，片足立て膝，あぐら，立て膝，正座の 
6 種類の快適支持面形状を探索した. 支持面のばね定数 は好みの最終安定形状に影響しないことから5), 沈み込 みの少ない $60 \mathrm{~N} / \mathrm{mm}$ とした。

作業内容は, ダイニングにおいて高頻度で行われてい

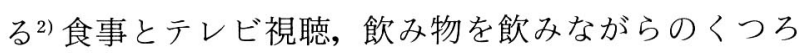
ぎ, 筆記, A 4 型ノートパソコンによる作業, 新聞読み とした。

実験風景を図 3 に示す。支持面の初期形状は軽休唕用 椅子として提案されている寸法, 角度条件 ${ }^{6)}$ を用い, 机面 高は市販品で最も多い $700 \mathrm{~mm}$ (250 点中 40\%) とした.

\section{2-2. 座面の特徵}

図 4 に各姿勢における快適な座面形状と反力の例を示 す。図 4 (c)のあぐらと図 4 (d)の片足あぐらでは座面前部 をくぼめている。これはくるぶしの圧迫をさけるためで ある。また, 図 4 (e)の立て㯟と(f)の片足立て㯟では, 座 面前部を土踏まずにあわせて凸面にしており,さらに大 腿屈曲による腹部の圧迫を避けるために, 座面を長くし ている.一方, 図 4 (a)の通常座位と(b)の正座では座面前 部を平らにしている.

座面後部は, 正座では全体的に平らであるが, 他の姿 勢では慰部を沈み込ませた形状になった。臂部が最も沈 み込んでいる位置を最凹点，極大となる位置を折れ点と

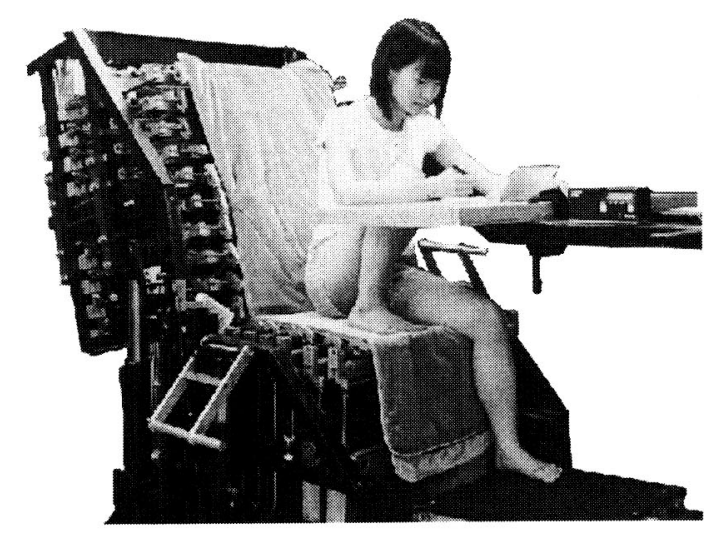

図 3 形状可変実験椅子を用いた計測風景

Fig. 3 Experimental view.
し，折れ点を通る水平線と背もたれの正中線の交点を七 ンジポイントとした.

図 5 にヒンジポイントを原点とした折れ点と最凹点の 分布を示す．最凹点はヒンジポイントに近くて深いグ ループと, ヒンジポイントから遠くて浅いグループに分 かれ，ヒンジポイントから約 90〜 $165 \mathrm{~mm}$ に分布した.

\section{2-3. 座面構造と基本寸法}

正座以外では腎部を沈ませることを好む共通の傾向が 見られたが，座面前部の快適形状は姿勢によって大きく 異なることがわかった。このため，図 6 (a)に示すように 座面を前座面と後座面の二つに分割し, 前座面をスライ ド・傾斜させることで多姿勢に対応できるようにした。

座面の最小長さは, 低身長者でも溙毫への圧迫が生じ ないように, 座位臂・膝窩距離の女性 5\% tile 值 406

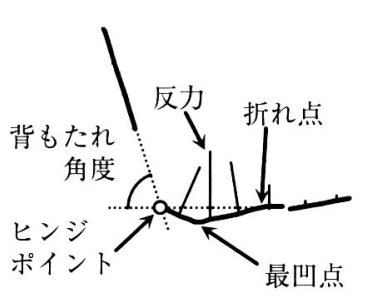

(a) 通常座位

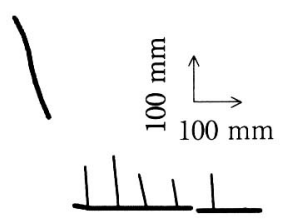

(b) 正座
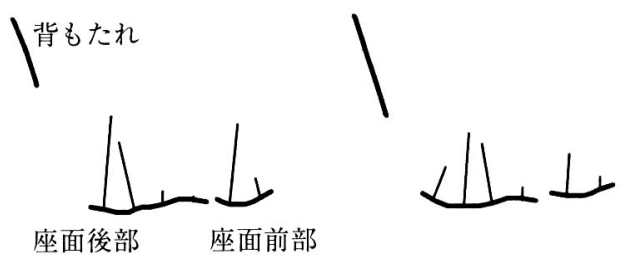

(c) あぐら

(d) 片足あぐら

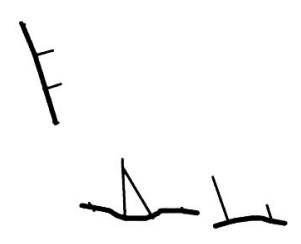

(e) 立て膝

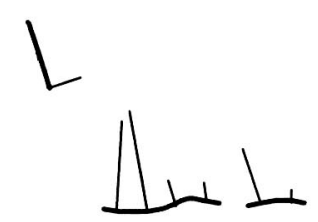

（f）片足立て膝
図 4 各姿勢の形状と反力例

Fig. 4 Example of surface shape and reaction force.

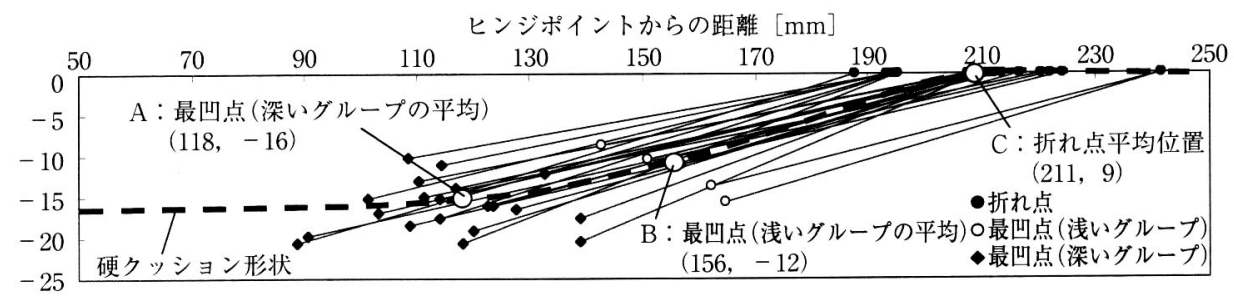

図 5 最凹点と折れ点㧍よびクッション形状

Fig. 5 The cushion surface shape designed from distribution of the most-concaved points and bent. 
$\mathrm{mm}^{7}$ を参考にして $400 \mathrm{~mm}$ (ヒンジポイントから先端 まで）とした。また，座位剧幅の成人男性 95\% tile 值は $400 \mathrm{~mm}^{7)}$ であるため, 肘掛け幅および多姿勢のための 余裕を考慮し，座面幅は $460 \mathrm{~mm}$ とした. 4 人掛けダイ ニングテーブル約 250 点を調査した結果, 最も一般的な 幅は $1,500 \mathrm{~mm}(17 \%)$, 次が 1,350 mm（16\%）で あったため, $460 \mathrm{~mm}$ でも十分に 2 脚並べることができ る.さらに小原らが提案した座面が水平に近いプロト夕 イプ ${ }^{6)}$ を参考に, 座面前端高の実用値 $405 \mathrm{~mm}$ から ヒール高 $25 \mathrm{~mm}$ を引いた $380 \mathrm{~mm}$ を座面高とし，これ を坐骨結節高とした。

この確認のため, 表 1 に示す被験者 4 名に, 少なくと も片足が床面につく様々な姿勢をとらせ，それぞれの好 みの座面高を測定した結果, 座面高は $380 \pm 19 \mathrm{~mm}$ と なり，設計值とほぼ一致した。

\section{2-4. 後座面}

図 6 (a)に示すように, 臂部の沈み込み形状に対応した 硬いクッション層 $(66 \mathrm{~N} / \mathrm{mm}$, 押し込み棒 $\phi 6 \mathrm{~mm})$ と, 正座に対応する表面が平らな軟らかいクッション層 $(0.36 \mathrm{~N} / \mathrm{mm})$ の 2 層構造にした。

硬クッション層は, 図 5 の破線で示すように, 最凹点 が深いグループの平均值 $\mathrm{A}$ 点, 浅いグループの最凹点 平均值 B 点, ヒンジポイントから折れ点までの平均距 離 $\mathrm{C}$ 点を通り， $\mathrm{A}$ 点より後ろと $\mathrm{C}$ 点より前の平面部と を滑らかに接続する曲線とし, 様々な姿勢と好みの着座 位置に対応できるようにした。

また，正座では足先が慰部の後方に出るために，ヒン ジポイントの後方まで座面を延長した. 延長量は, 表 1 に示す 5 名（ほぼ男女平均土 $25 \%$ tile 相当）の正座時の ヒンジポイントからつま先までの距離が最大 $91 \mathrm{~mm}$ あったため, 余裕を見て $100 \mathrm{~mm}$ とした.さらに, 延 長部を $R 205 \mathrm{~mm}$ の円弧で滑らかに結び，足背部の圧 迫を緩和した。

\section{2-5． 前座面}

あぐらと片足あぐらでの腓骨外果への圧迫を避けるた めに，図6(b)のように前座面の表面のクッションを軟ら かくし $(0.36 \mathrm{~N} / \mathrm{mm})$ ，前端は通常座位に対応するよう に回転中心 $\mathrm{O}$ から半径 $25 \mathrm{~mm}$ の丸みをつけた。また， 立て膝やあぐら時に足が前方に落ちないように，図 4 に 例を示した快適座面形状デー夕から前座面を $25^{\circ}$ まで傾 けられるようにし，無荷重のときはトルクばねとストッ パーで水平に戻るようにした。さらに，後座面との隙間 に中間座面を設置し, 前座面がスライドしたときに足が
落ちないようにした。

前座面のスライド量を決定するために，表 1 に示す被 験者 6 名に, 3 章に示す約 70 度の背もたれに寄りかか らせ，自然に立て膝をした状態（自然な状態）と無理が ない程度に踵を引き付けて立て膝をした状態（笨屈な状 態）の 2 種類の姿勢をとらせ，両姿勢の骨格特徴点を空 間座標計測装置（小坂製作所：VECTORON）で計測 した。結果を図 7 に示す。ヒンジポイントから足部中心 （踵点とつま先点の中心）までの距離は，自然な状態で $640 \pm 60 \mathrm{~mm}$ ，窮屈な状態で $406 \pm 76 \mathrm{~mm}$ であった。こ れより，前座面をスライドしたときのヒンジポイントか ら前座面の回転中心までの距離が $406+76=482 \mathrm{~mm}$ 以 上となるように，前座面のスライド量を $120 \mathrm{~mm}$ とした。

踵を無理なく引き寄せられる距離は, 体節長, 肥満 度，体の柔らかさなどに依存する。表 1 の全被験者 24 名へのアンケート調査では, 脚が長くて座面に脚を乗せ にくくなる身長 $170 \mathrm{~cm}$ 以上, 腹部が圧迫される BMI $25 \mathrm{~kg} / \mathrm{m}^{2}$ 以上，体が硬い立位体前屈 $0 \mathrm{~cm}$ 以下の いずれかに該当する人は，日常生活のなかで椅子上では 立て膝をしない傾向があった。

\section{3. 背もたれ}

2 章の実験で得られた好みの背もたれ角度は, テレビ 視聴時で $62 \pm 4^{\circ} ， お$ 茶を飲むなどの姿勢では $69 \pm 3^{\circ}$ で あった。アンケート調査結果によれば，食後も飲食を伴 うくつろぎが多いため, 背もたれ角度は飲食に適した $70^{\circ}$ に固定した。

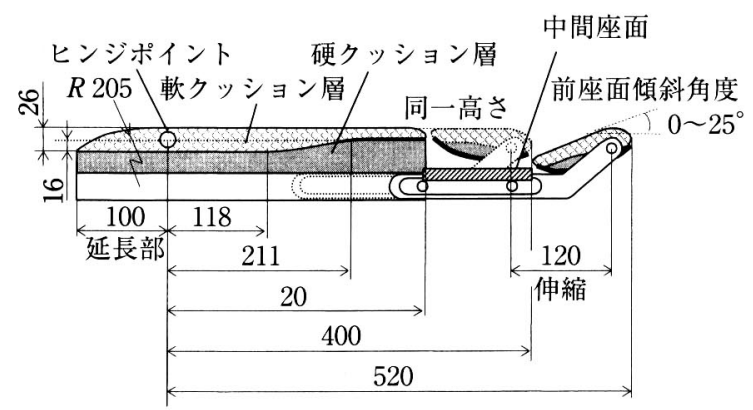

(a) 座面構造

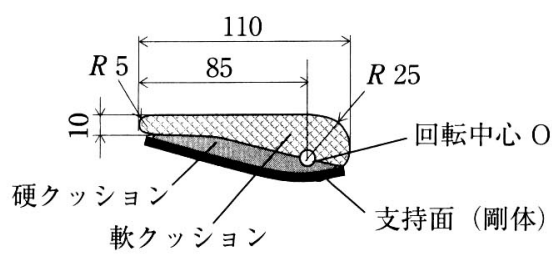

(b) 前座面

図 6 座面案

Fig. 6 Seat design. 
背もたれの形状を決定するために, 形状可変式実験椅 子4) を用い，表 1 に示す 7 名に 2 章と同様の 6 姿勢をと らせ, 好みの背もたれ形状を探索した. その結果, 正座 では背もたれ下部と慰部が干渉するため, ヒンジポイン トから背もたれ面方向に $330 \mathrm{~mm}$ までをくぼませる形 状を好んだ。あぐら，片足あぐら，立て膝では，図 8(a) (b)のようにほ湆線を好む被験者と, 図 $8(\mathrm{c})(\mathrm{d})$ のように 腰部をくぼませる形状を好む被験者がいた，反力は図 8 (a)(c)に示すように, 腰部で大きくなる場合と図 8 (b)(d)の ように胸部で大きくなる場合があった。また，いずれの 場合もヒンジポイントから背もたれ面方向の $130 \mathrm{~mm}$ までは反力が掛かっていなかった.

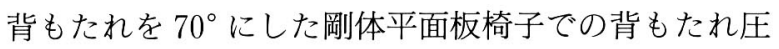
力をシート型圧力センサ（ニッタ：Big Mat）で計測し た結果，腰部に荷重を掛ける被験者 n（表 1）は，図 9 の破線で示すように背筋部で支えていたが，胸部で支持 していた被験者 $\mathrm{r}$ は背筋が薄く, 図 9 の実線で示すよう
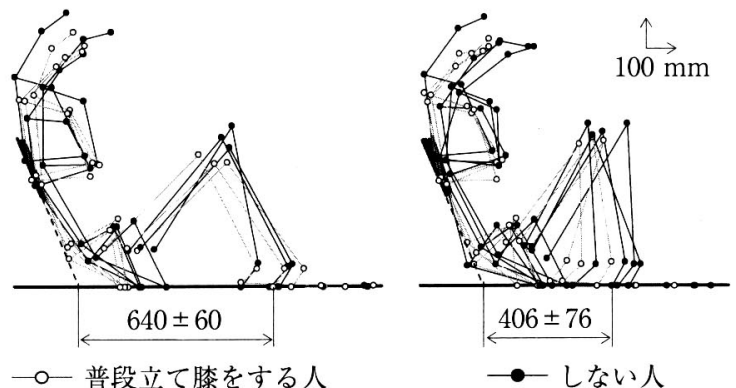

図 7 立て㯟姿勢

Fig. 7 "Tatehiza" posture.

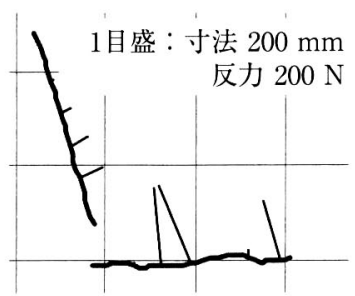

(a) 直線型 - 反力腰

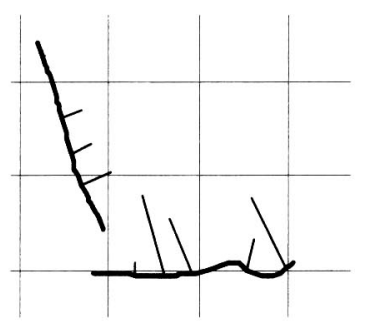

(c) 凹型 ・ 反力腰

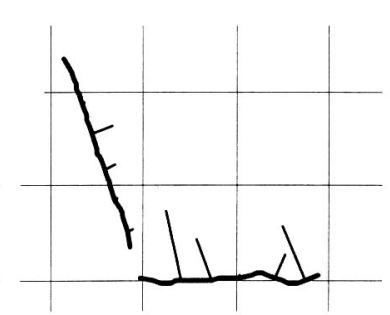

(b) 直線型・ 反力胸

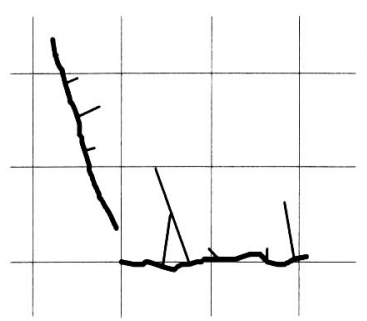

(d) 凹型・反力胸
図 8 背もたれの好みの形状と反力（あぐら）

Fig. 8 Seat surface shape and reaction force during "agura”.
に圧力が棘突起に集中していた。この棘突起の痛みを避 けるために，図 8(d)では背もたれ下部を窪ませ，図 8 (b) では腰部が接しないように浅く着座して, 胸部の反力が 大きくなったと考えられる。

このため背もたれ下部を大きく空けるか, 変形しやす くする必要がある. 後述図 12 の一次試作では，下部を $330 \mathrm{~mm}$ 空けたが, 支持感が不足したため, 二次試作で は，正座時に足部が入る隙間として反力がかからない $130 \mathrm{~mm}$ までを空けた。また，背もたれの下部方向に クッションを厚くし, サポート感と痛みの回避を両立さ せた（上端部 $0.2 \mathrm{~N} / \mathrm{mm}$ ，下端部 $0.1 \mathrm{~N} / \mathrm{mm}$ ).さら に，背骨への圧迫を避けるため，腰部に横 $R(R=800$ $\mathrm{mm}$ )を付けた。

二次試作では，横向き座りをしたときに，背もたれ上 端に肘や頭部を乗せることができるように，背もたれ上 端に厚みと柔軟性を持たせ，时掛なしとした。

全体の高さは配膳のしやすさを考慮して立位时頭高の 女性 $5 \%$ tile 值 $910 \mathrm{~mm}^{7)}$ とした。また，椅子を引くと きに必要な引き手部の高さは立位握り軸高の男性 $95 \%$ tile 值である $810 \mathrm{~mm}^{7)}$ とした。

\section{4. 肘掛け}

あぐらなどの姿勢では，肘掛けが大腿と干渉する可能 性がある。このため表 1 に示す被験者 5 名のあぐら時の 大腿上面㧍よび側面の最外郭を空間座標計測装置で計測 した，左右の坐骨結節の中心を重ね合わせた結果を図 10 に示す。図 10 (a)の上面図より，时掛け内側の間隔を 座面幅の $460 \mathrm{~mm}$ とし，肘掛けの高さを標準寸法の 230 $\mathrm{mm}$ (坐骨結節点からの高さ) ${ }^{3)}$ としとき，坐骨結節 の前方 $47 \mathrm{~mm}$ の位置で大腿と接することがわかる. 2 章の実験において，坐骨結節の位置がヒンジポイントに 最も近かったのは，女性被験者 c（身長 $2.5 \%$ tile 相当） の $90 \mathrm{~mm}$ であったため, 肘掛けの支柱がヒンジポイン

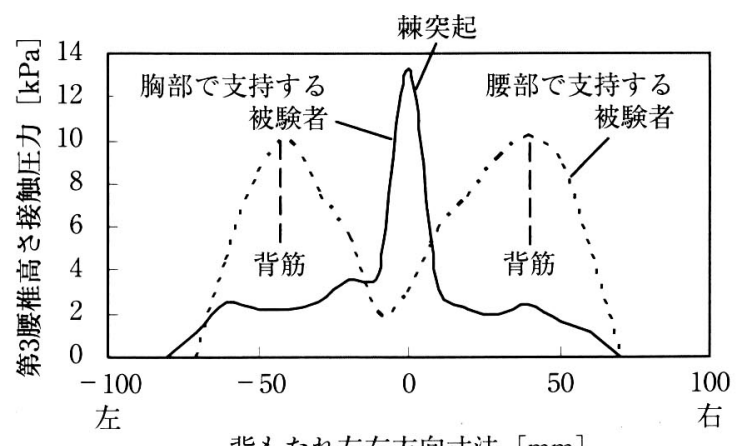

背もたれ左右方向寸法 $[\mathrm{mm}]$

図 9 腰部（L 3 付近）の幅方向背もたれ圧力分布

Fig. 9 Pressure distribution at L 3 level. 
トから $137 \mathrm{~mm}(90+47 \mathrm{~mm})$ 以内であれば，あぐら姿 勢の大腿に干渉しない. また, 図 10 (b)の側面図から, 肘 掛前端位置での大腿上面の最大高さは男性被験者 $\mathrm{s}$ (体 重 $97.5 \%$ tile 相当）の $170 \mathrm{~mm}$ であったため，时掛け下 面の高さはこれ以上にする必要があることがわかる。

以上の設計寸法を図 11 に，試作した椅子を図 12 に示 す。二次試作では，肘掛けの効果を検討するためにあえ て肘掛けをつけなかったが，一次試作と同様の肘掛をつ けることもできる.

\section{5. 評 価}

\section{5-1． 短時間着座快適性}

図 12 (b)の二次試作椅子と図 13 および表 2 に示す 3 脚 の椅子に着座させ，筋電と姿勢の計測および官能検査を 行った。なお，市販椅子の座面高は坐骨結節高で定義し たが，表 2 では市販椅子に合わせ，座表面の高さで表示

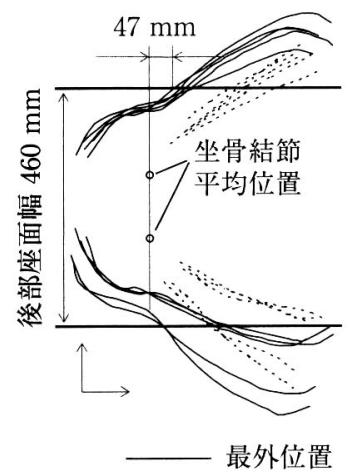

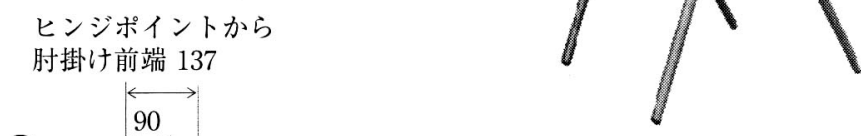

(a) 肘掛けあり (一次試作)

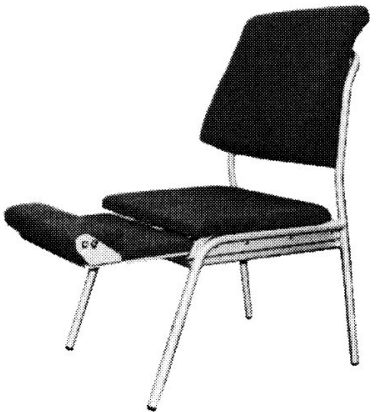

(b) 肘掛けなし （二次試作）
図 12 試作椅子

Fig. 12 Chair prototype.

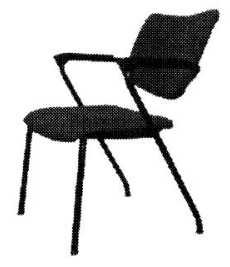

(a) 椅子 $\mathrm{A}$

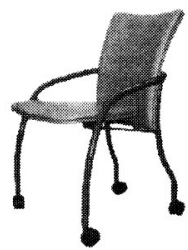

(b) 椅子 B

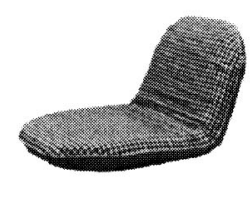

(c) 座椅子
図 13 対照椅子

Fig. 13 Chairs for comparison.

表 2 試作椅子と対照椅子の寸法

Tab. 2 Size of chairs.

\begin{tabular}{|c|c|c|c|c|}
\hline & 試作椅子 & 椅子 A & 椅子 B & 座椅子 \\
\hline 座表面高 [mm] & 406 & 420 & 440 & 70 \\
\hline 座面長 & 400 & 460 & 390 & 430 \\
\hline 座面幅 & 460 & 450 & 370 & 450 \\
\hline 座面角度 $[\mathrm{deg}]$ & 0 & 5 & 3 & 0 \\
\hline 背面長 & 530 & 390 & 380 & 300 \\
\hline 背面角度 $[\mathrm{mm}]$ & 70 & 73 & 72 & 73 \\
\hline
\end{tabular}


除去した後, 整流, 平滑化（遮断周波数 $1 \mathrm{~Hz}$ ) し, 計 測開始 1 秒後から 3 秒間の電圧平均値を筋活動量とし た。さらに，スッールに体幹を直立させて着座したとき の平均電圧を基準值とし, 計測值を基準值で除した值で 椅子間の比較を行った.

図 14 亿示すように試作椅子の快適性は，対照椅子よ りもすべて高いか同程度の評価であった．図 14 (b)に示 す座面の快適性においては，特に立て滕とあぐらで，対 照椅子に比べて評価が高かった。これは腹部（剣状突起 点一上前腸骨棘点）と大腿（転子点-大腿骨外側上顆点） の挟み角が対照椅子 $\mathrm{A}$ では立て膝 $39 \pm 13^{\circ}$, あぐら $89 \pm 17^{\circ}$ であり, Bでは, 立て膝 $37 \pm 14^{\circ}$, あぐら $91 \pm 17^{\circ}$, であったのに対し, 試作椅子では立て膝 $49 \pm 13^{\circ}$, あぐら $100 \pm 13^{\circ}$ と大きく, 腹部の笨屈感が解 消されているためである，さらに，立て滕と片足立て膝 では，背中が曲がっている程度を表す胸郭（第 1 胸椎 点-第 10 胸椎点）と骨盤（坐骨結節点-上後腸骨棘点） との挟み角が，対照椅子に比べて約 $10^{\circ}$ 大きくなってお り，背中の曲がりが改善されていた。

また，図 15 に示すように，筋電計測においても，立 て膝と片足立て膝時には足部の滑りを防ぐために背屈さ せる前脛骨筋の活動が, 試作椅子では対照椅子 A，Bの 5〜20\%程度であり, 楽な姿勢が保たれていることがわ かる．ただし前脛骨筋以外の筋活動は, 被験者や椅子に よっても異なり, 姿勢についての共通の傾向はなかった。

肘掛けについては姿勢変更時には机面で支えられるた め不要であるが，立ち上がり時にはあったほうが楽とい う意見があった。一次試作のように短い时掛であれば机 との干渉もさけられるため，つけたほうがよいと考えら れる。

\section{5-2. 多姿勢の意義}

一定姿勢をとり続けると特定部位が圧迫されるため, これを長時間続けることは困難である ${ }^{8)}$. 特に崩れた姿 勢では特定部位に負荷が集中することが多く，短時間で 姿勢を変化させながら負担部位を交換していくため, 姿 勢の多様性が高まると考えられる。

このため, 日常的に椅子で様々な姿勢をとる表 1 に示 す被験者 3 名にテレビ視聴を行わせ, 二次試作椅子で 20 分間の通常座位の後, 20 分ごとに自由に姿勢を変化 させ, 合計 80 分間着座したときの下腿のむくみを計測 した、計測前のむくみを一定状態にするため, 計測開始 直前に 5 分間の歩行運動を行わせた. 姿勢維持時間を統 制したのは, 姿勢変化間隔の個体差と個体内変動が大き いためである8．また，表 1 亿示す被験者 5 名について

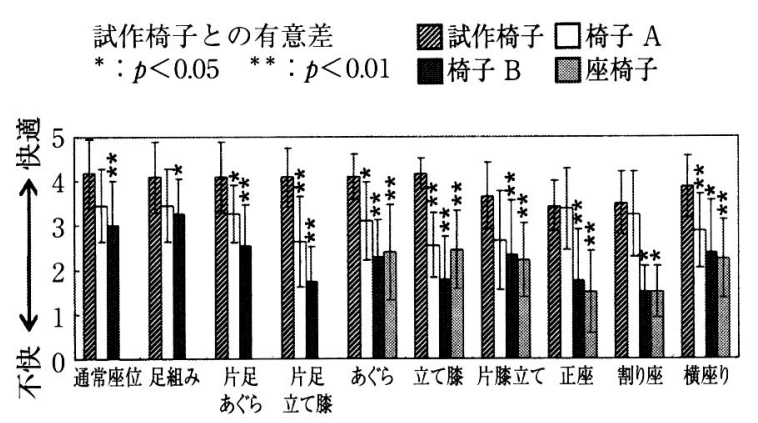

(a) 総合的な快適性

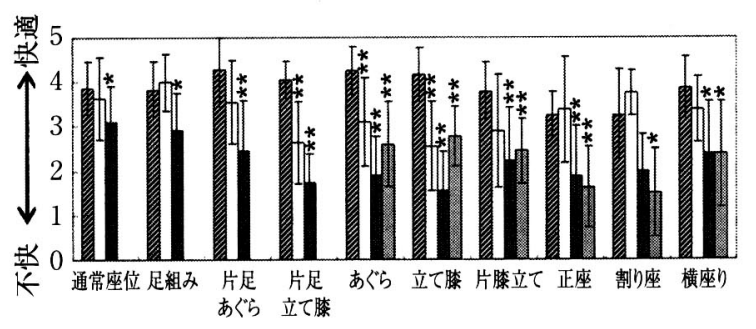

（b）座面の快適性

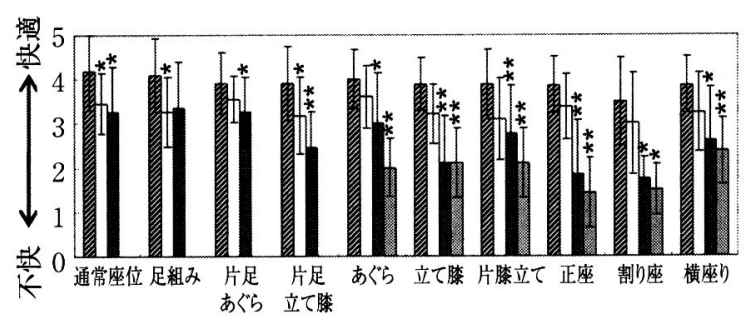

(c) 背もたれの快適性

図 14 官能検査結果 (平均, 標準偏差)

Fig. 14 Sensory evaluation result.

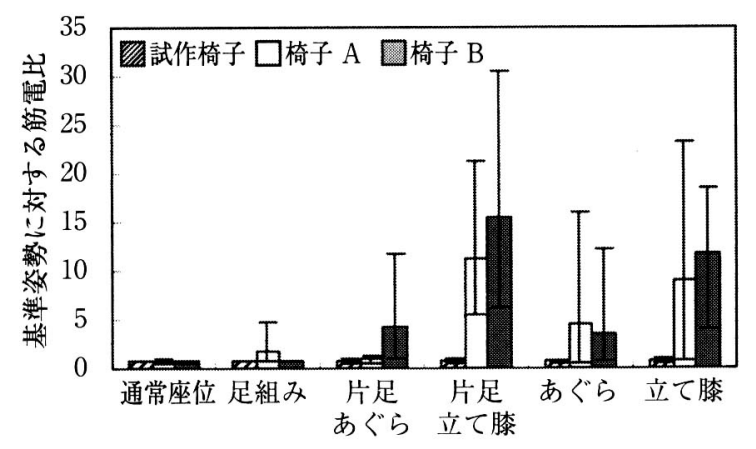

図 15 前脛骨筋活動 (平均, 最大, 最小)

Fig. 15 Tibialis anterior activity (mean, max, min.).

各姿勢の体圧分布をシート型圧力センサ（ニッタ：Big Mat）で計測した。

下肢のむくみは 4 電極法多周波数体脂肪計（積水化学 工業：MLT-30）を用いた生体電気インピーダンス 法9,10)で計測し，周波数 0 のときの推定抵抗值を $R_{0}$ と して $1 / R_{0}$ をむくみの指標とした，下肢のむくみ計測で は一般に下肢の外側に電極を貼付するが，この方法では あぐらなどの姿勢をとると電極が圧迫される。このた 


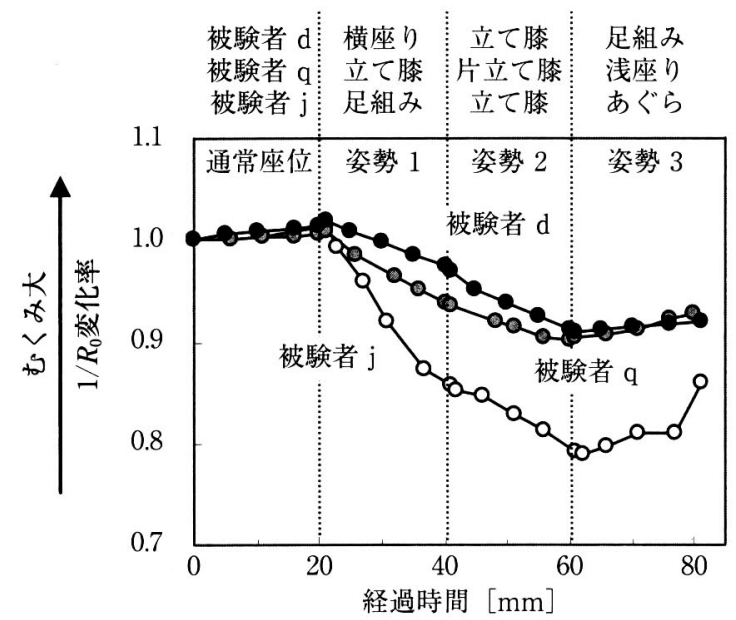

図 16 むくみ変化

Fig. 16 Change rate of swelling.

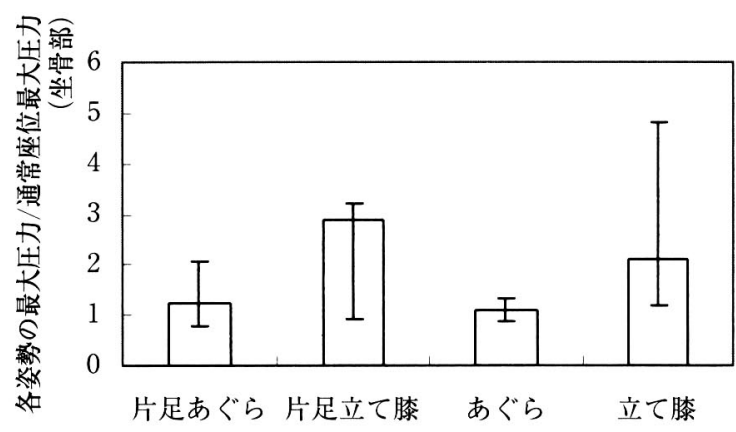

図 17 坐骨部の最大圧力比 (平均, 最大, 最小)

Fig. 17 The maximum pressure rate at the buttock.

め, 電極は下腿の内側に貼ることとした。この方法で も, 通常の外側貼付の結果と差がないことを確認した. また， $1 / R_{0}$ は，姿勢変化時の体組織の変形によっても 大きく変化する。このため, 短時間ではむくみの状態は 変わらないと仮定し， $1 / R_{0}$ 值に含まれる姿勢変化の影 響を, 各姿勢の短時間の $1 / R_{0}$ 值と立位の $1 / R_{0}$ の比とし てあらかじめ計測し，これを長時間計測における計測值 にかけることで，むくみの変化を連続化させた。

図 16 に初期むくみ量に対する 5 分ごとのむくみの変 化率を示す. 被験者 $\mathrm{d}$ は通常座位 $\rightarrow$ 横座り $\rightarrow$ 立て膝 $\rightarrow$ 足組み, 被験者 $\mathrm{q}$ は通常座位 $\rightarrow$ 立て㯟 $\rightarrow$ 片足立て膝 $\rightarrow$ 浅座り, 被験者 $\mathrm{j}$ は通常座位 $\rightarrow$ 足組み $\rightarrow$ 立て㯟 $\rightarrow$ あ゙ら と姿勢を変化させた。通常座位後の姿勢 $1 \sim 3$ は被験者 ごとに異なる姿勢をとっているにもかかわらず，図 16 の姿勢 1,2 ではむくみが軽減し, 姿勢 3 では姿勢によ らずむくみが上昇していた。

図 17 に通常座位時の坐骨部最大圧力に対する各姿勢 の最大圧力の比を示す. 片足立て膝では通常座位に比べ
て約 3 倍, 立て膝では約 2 倍高いことがわかる.この結 果から，下腿のむくみを軽減するように足をあげ，むく みが解消すると，坐骨部の圧力を軽減するか，腹部など が圧迫されない姿勢をとるなど，多姿勢をとることで長 時間の着座を可能にしていると考えられる。この効果は 従来の椅子でも期待できるが，試作椅子ではより容易に 多姿勢がとれる特長がある。

\section{6. おわりに}

座面を 2 分割し，前部を $120 \mathrm{~mm}$ 伸長させ， $25^{\circ}$ 回転 させることで，立て膝，あぐら，正座などの多様な姿勢 に対応できるダイニングチェアを開発した。

各姿勢の負担箇所は異なるため, 多様な姿勢をとりや すくすることで，テレビ視聴などの長時間の着座が可能 になる。また，多姿勢は畳文化の特徴でもあり，提案し た椅子はリラックス・プライベート空間における新たな 可能性を示している.

椅子の試作にはコクヨ(㧣の協力を得た。ここに記して 謝意を表する。

\section{参考文献}

1）沢田知子：ユ力座・イス座, 星雲社, 1995 .

2）中村久美, 今井範子：リビングダイニングの住生活に おける収納の問題, 日本家政学会誌, 53(1), 43〜 56, 2002.

3）中瀬博幸, 中岡正典：人に優しい家具・インテリア (第 1 報)，徳島県工業技術センター研究報告， $7,81 \sim 84$, 1998.

4）山崎信寿, 佐々木貴弘, 相沢淳平：個別適合条件の探索 を目的とした可変クッション椅子の開発，人間工学, 33(5), 211〜218, 1997.

5）山崎信寿，諸永裕一：短時間休息用剛体支持面安楽寝 椅子の形状適合化, 人間工学, 36(1), 29 37, 2000.

6）小原二郎, 内田祥哉，宇野英隆：建築 - 室内 -人間工 学, 122 127, 鹿島出版会, 1969.

7）人間生活工学研究センター：日本人の人体計測デー 夕, 社団法人人間生活工学研究センター, 1997.

8）加藤麻樹, 武岡 元, 石田敏郎：事務用回転椅子の圧力 分布の時系列変化に関する研究, 人間工学, 33(6), 343 349, 1997

9) A. Seo, Y. Kondo \& F. Yoshinaga: A Portable Apparatus for Monitoring Leg Swelling by Bioelectrical Impedance Measurement, Journal of Occupational Health, 39, 150 151, 1997.

10）川上 慶，山崎信寿：下腿のむくみを軽減する女性用 オフィスチェアの開発, 人間工学, 41 (特別号), 360～361, 2005. 